UDK 364.2:316.37

Вјекослав Бутиган ${ }^{1}$

Универзитет у Нишу

Филозофски факултет у Нишу

\title{
МОЋ „АКЦИЈАШКИХ ПОЗИТИВНИХ КАРАКТЕРИСТИКА“ И НЕМОЪ ДА СЕ ВЕЛИКИМ ГРУПАМА БРИГАДИРА ОСПОРИ ДОБРОВОЉНОСТ И НЕСЕБИЧНОСТ УЧЕШЋА У ОМЛАДИНСКИМ РАДНИМ АКЦИЈАМА
}

\begin{abstract}
Резиме
Текст је настао као реакција на рад: „Омладинске радне акције у Југославији и могућности њиховог поновног организовања", Горана Николића, објављеног у Пиротском зборнику бр. 41. У њему се оповргавају тврдње изнете у поменутом раду да су постојале акцијашке карактеристике у првих 20 година организовања омладинских радних акција у социјалистичкој Југославији, и да су због њих наведене групе омладинаца одлазиле на радне акције и користиле их за остваривање неких привилегија, професионалних, политичких и других руководећих каријера. Одбацују се тврдње да су „млади сеоски учитељи“ ишли на омладинске радне акције и политички се ангажовали у жељи да добију позитивну карактеристику и као такви да од надлежних школских власти издејствују бржи премештај у град. Одбацује се и исказ да су се исто тако понашали и они који су се тек спремали за учитељски позив - ученици учитељских школа, jер чињенично нису засноване, нити аргументоване. Побија се тврдња да су руководиоци радних бригада и поједини акцијаши помоћу „акцијашких позитивних карактеристика“ остваривали академске, научне и универзитетске каријере, руководеће положаје у привредним организацијама и установама. Оспорава се исказ да наведене групе омладинаца нису ишле на омладинске радне акције „истински добровољно и несебично“, већ због „акцијашких позитивних карактеристика“, материјалне користи и разних привилегија. Најзад, указује се на методолошку и логичку некоректност у интерпретацији неких података у вези са пре-
\end{abstract}

\footnotetext{
1 butigan.pi@ sbb.rs

2 Ову научну критику (у нешто ширем обиму) одбили су да штампају у „Пиротском зборнку“ бр. 42. чланови редакције: Драгољуб Златковић, агроном у пензији и публициста у области фолклора југоисточне Србије, Владица Тошић, професор историје и потпредседник Скупштине града Пирот, Надежда Ћирић, професор књижевности и српског језика у пензији, и главни и одговрни уредник Горан Николић, дипломирани политиколог. Тиме су онемогућили оповргавање неистините тврдње изнете у броју 41 да је, међу осталим, седморо некадашњих професора Филозофског факултета у Нишу и 10 најугледнијих некадашњих ученика и професора из алумне на порталу Високе школе струковних студија за образовање васпитача у Пироту, стекло успешне научне и стручне каријере помоћу „позитивних акцијашких карактеристика“: 4 декана, 2 продекана, 4 директора више и 1 високе школе. Исто су поступили са још три критике (две аутора који су доктори наука) супротно свим правним, етичким и академским нормама.
} 
тходним тврдњама аутора текста о радним акцијама и изведеним закључцима.

Кључне речи: акцијашке карактеристике, млади сеоски учитељи, ученици учитељских школа, каријере, функционери.

У Пиротском зборнику 41/2016. године објављен је текст: „Радне акције у социјалистичкој Југославији и могућности њиховог поновног организовања", као “монографска студија". ${ }^{3}$ Рад има више делова а међу њима су и делови са насловима: "Радне акције у прве две послератне деценије“, „Радне акције од половине шездесетих до урушавања социјализма“ и „Анкета о радним акцијама међу средњошколцима, могућност практичног обнављања акција“. У првом делу рада постоје провокативне ,дискутабилне и неистините констатације о неким групама и појединцима - учесницима у омладинским радним акцијама из Пирота.

Један од циљева рада био је да, насупрот наративу ветерана добровољних омладинских радних акција о ентузијазму, патриотизму, радном хероизму и подвизима учесника на овим акцијама, на неколико примера покаже да у првих 20 година социјалистичке Југославије, „за неке бригадире одлазак на акцију није био истински добровољан, односно несебичан“" (Николић, 2016: 208), уколико су ишли на радне акције да добију „позитивне карактеристике“ помоћу којих су остварили материјалне користи, друштвене привилегије, политичке и професионалне каријере. У тексту стоји да је, с обзиром на руководећу улогу Партије у свим областима живота за сваког појединца било врло битно нешто што се звало карактеристика - мишљење представника партијске власти о конкретној особи. Они који су имали позитивну карактеристику лакше су се запошљавали и напредовали на послу, лакше добијали стан... могли су да се надају... да ће се лакше уписати на атрактивне факултете, или добити стипендију, итд (Николић, 2016: 168, 169, болд В. Б.).

Када би те привилегије остварили, пише Николић, „неки су настојали да се лагано и неприметно повуку из омладинске организације или Партије. Добар пример за то могу да буду млади сеоски учитељи“ (Николић, 2016: 170, болд В. Б.). ${ }^{4}$ У Среском комитету Народне омладине у Пироту 1956. године „скоро половина његових чланова били су сеоски учитељи, без обзира на њихов врло мален број у односу на укупно становништво. Да ли су то сеоск учитељи

3 Рад је погрешно категорисан као монографска студија, јер не испуњава услове предвиђене Актом о уређивању часописа ресорног министарства, Правилником о поступку начина вреднована и квантитативном исказивану научно-истраживачких резултата истраживача, библиографске услове, етичке и академске стандарде. Такође, приликом класификовања овог рада и одлучивања о његовом објављивању, уредник је био истовремено и аутор, а тиме у сукобу интереса, што подлеже одговарајућим санкцијама Одбора за праћење примене етичких стандарда у уређивању yaconuca COPE (Committee on Publication Ethics).

4 Синтагма „сеоски учитељ“ у наративу једног броја интелектуалаца има омаловажавајуће значење, недовољно култивисаног учитеља, који се „посељачио“, не разликујући се много од осталих становника села. 
више волели радне акције, омладинску организацију и социјализам од других?““ (Николић, 2016: 170, 171, болд В. Б.). Неки од њих су се „политички ангажовали у жељи да добију позитивну карактеристику и као такви да од надлежних школских власти издејствују бржи премештај у град. Исто су се понашали и они који су се тек спремали за учитељски позив - ученици учитељских школа“" (Николић, 2016: 171, болд В. Б.).

Из рада се не види из ког извора се дошло до сазнања о постојању „карактеристика представника партијске власти“ о младим учитељима или гимназијалцима. Само у два цитата наводе се тврдња Миодрага Станковића “морали смо да имамо и мишљење омладинске организације шта да студирамо“ и ПетраАлексића (уписао Филолошки факултет 1949) да се “на медицински, стоматолошки и технички факултет ниси могао уписати ако немаш писану препоруку, карактеристику, омладинске организације“ (Николић, 2016: 168, болд В. Б.). Иако није био ни на једној радној акцији и био и третиран као ,„реакција“, био је в. д. директора Учитељске школе у Пироту 1961-1962. године.

У том периоду, стоји у тексту, нарочито после рата када је постојао тоталитарни систем по совјетском узору, за неке бригадире одлазак на акцију, није био истински добровољан, односно несебичан. Акције су тада биле значајан канал вертикалне друштвене покретљивости и учешће на њима индиректно и на дуже стазе могло је да им омогући извесно материјално напредовање (Николић, 2016: 208, болд В. Б). У периоду политичке либерализације, пиш даље у тексту: „карактеристика, губи значај који је имала а присуство младих сеоских учитеља на радним акцијама и у омладинској организацији током седамдесетих и осамдесетих година готово ишчезава“ (Николић, 2016: 172, болд В. Б.). Није спорно да је приличан број младих са села ишао на радне акције да поред добровољног рада стекне неку квалификацију за рад у индустрији. Треба истаћи да су сеоске омладинске радне бригаде дале највећи допринос у извођењу радова на тим акцијама, с обзиром на трајање смена (2-3 месеца), најтеже послове које су обављали и учинке које су оствариле.

Од великог броја „младих сеоских учитеља“ - учесника у омладинским радним акцијама, у Југославији и Пиротском срезу, који су ишли на радне акције и политички се ангажовали да „добију позитивну карактеристику“, тј. нису „истински добровољно, односно несебично ишли на радне акције“, наведени су: Видоје Миленковић, наставник ${ }^{5}$ у Великој Лукањи и председник тамошњег МК СО командант бригаде на пошумљавању Средњег Висока 1964,... Нешто раније до 1959, док су у тим селима - рејонским центрима још увек постојале општине, учитељи су били председници општинских комитета Народне омладине, попут Драгослава Војчића у Великој Лукањи и Правдољуба Николића у Темској, односно команданти радних акција на том терену, као на пример учитељ Вјекослав Бутиган на изградњи пута Темска - Топли До.... (Николић, 2016: 171, у фусноти).

5 Учитељ у предметној настави. 
... др Миомир Ивковић, професор и декан Филозофског факултета у Нишу, као учитељ у Чиниглавцима, био је секретар МК у Сукову, па секретар пиротске омладинске организације и руководилац бригадирског насеља на поправци пута за Висок 1965. (Николић, 2016: 180).

1. Напред наведеним тврдњама изречено је више неистина. Ниједан од именованих у цитираном тексту није добио место учитеља у градској школи. Они се нису као учитељи политички ангажовали у омладинској организацији, већ још као ученици - омладински активисти, а затим су само наставили своје ангажовање у сеоској средини. Били су међу најбољим ученицима, са највишим службеним оценама као учитељи (неки и награђивани) и у то време међу бољим ванредним студентима, па им никакве друге „позитивне карактеристике“ нису биле потребне за бржи долазак у град. С обзиром на то политичко ангажовање им је више сметало у студирању, него помагало за напредовање. Овој петорици додат је и Божидар Лилић. Прво је био учитељ у Ракити, затим у Височкој Ржани, истовремено и председник МКСО, командант бригаде у Широким Лукама 1963. године. Радно место учитеља у Основној школи „Вук Караџић добио је 1982. године (Цветков, 1995: 190), после више од 20 година рада у 4 сеоске школе. Преминуо је 1999. Године у 59. години. ${ }^{6}$ Слободан Димитријевић, учитељ сва четири разреда у селу Бели, некадашњи командант Треће омладинске раднебригаде (1958) и Врањско-пиротске (1959) на изградњи Аутопута у Словенији, наставио је рад у истом селу још 16 година. Умро је као учитељ у том селу, 1974. у 39. години, не дочекавши да дође да ради у неком већем селу (регионалном центру) нити у градској школи (Ђорђевић, Г. Н; Војчић, В. Д, 2001). Драгица Јаначковић, двоструки ударник, као учитељица радила је више година у селима.

У тексту, дакле, није наведен ниједан пример за горњу тврдњу о „сеоским младим учитељима“. Позивање на изјаву Боривоја Митровића која, наводно, потврђује истинитост наведене тврдње, обеснажена је од самог Митровића који то пориче. Напред наведена тврдња о именованим младим учитељима који су се политички ангажовали и ишли на радне акције ради добијања „позитивних карактеристика““ да би од „школских власти издејствовали бржи премештај у град“ je, према томе, неистина и омаловажавање њиховог учешћа на већем броју омладинских радних акција.

Ови „млади сеоски учитељи“, када већ нису били ни млади, ни учитељи, у даљем тексту појавиће се у групи оних „који су акцијашењем стекли... позитивну карактеристику да су касније направили

6 Видети монографије о селима, школама и појединим генерацијама учитеља (1952, $1957,1958,1959)$. У колективном сећању становника села млади сеоски учитељи су и данас остали као марљиви и часни. Дана 15. 4. 2017. обавио сам интервју са Митровићем у вези са изјавом датој аутору рада и питао га: „Који су се млади сеоски учитељи толико истакли као омладинци да су брже премештени у град“? Тврдио је да то не зна и да то није рекао у разговору са аутором текста, нити је дао сагласност да се тако нешто објави. Миодраг Костић, референт и начелник Одсека за просвету и културу СО Пирот, шездесетих, потврдио је да ниједан учитељ на селу није премештен на рад у основну школу у граду због учешћа у омладинским радним акцијама. Саватије Велчев, референт за просвету у СО Пирот, тврдио је то исто, у изјави датој у интервјуу. 
врло успешне каријере“ (Николић. 2016: 172), ван Пирота и у Пироту, и то као професори средњих и виших школа, факултета, директори средњих и виших школа, доктори наука, декани факултета (Николић, 2000: 179, 180).

Међутим, за остварене каријере, млади сеоски учитељи нити су имали акцијашке карактеристике, нити су им биле потребне. С обзиром на интелектуални капацитет, емотивно-вољни склоп личности, личну културу рада, остварене резултате у раду и друге личне особине, они би жељене професионалне каријере успешно остварили а да ни један дан нису били на некој омладинској радној акцији, или „истакнути омладинци“. Знали су да им је најпоузданији канал вертикалне друштвене покретљивости рад на образовању и стручном усавршавању, а не акцијашење. Скоро да нема ученика Учитељске школе у Пироту, без касније стеченог вишег или високог образовања, стеченог уз рад.

Од политичког ангажовања младих сеоских учитеља највеће користи имали су мештани села, јер су ови учитељи добровољно и несебично организовали рад на: унапређивању задругарства, обнављању старих и изградњи нових школских зграда, домова културе, електрификацији села, увођењу телефона, изградњи путева, водовода, пошумљавању голети, припремању културно-уметничких приредби, одржавању разних предавања и курсева за мештане села. ${ }^{7}$ У томе $^{2}$ нису заостајале ни учитељице. Атаком на ученике учитељских школа и младе сеоске учитеље, извршена је морална дискредитација читаве професионалне групе учитеља, јер су сви они прошли кроз та два периода развоја.

Касније, када су обављали руководеће функције, неке су их обављали акцијашки, волонтерски, без икакве материјалне надокнаде (у локалној самоуправи, у културним и информативним институцијама, у уређивању часописа, друштвено-политичким и друштвеним организацијама).

2. Друга неистина изречена је у тврдњи да су се ученици учитељских школа „исто понашали као млади сеоски учитељи“, ишли на омладинске радне акције и политички се ангажовали због „позитивних карактеристика“, да би по завршетку школовања и службовању у селима „од надлежних школских власти издејствовали бржи премештај у град“. Напросто, не види се на основу чега се генерално тврди да су се „исто понашали ученици учитељских школа“, којих је само у Србији било 20.

Оповргавањем претходне тврдње о стигматизованим „сеоским младим учитељима“ потврђује се и неистинитост тврдње о „ученицима учитељских школа“, који су у младим „сеоским учитељима“ могли да имају само позитивне узоре а не негативне. У раду није дат ниједан доказ да су се ученици било које учитељске школе у Србији понаша-

7 Видети монографије о селима, школама и појединим генерацијама учитеља (1952, $1957,1958,1959)$. У колективном сећању становника села млади сеоски учитељи су и данас остали као марљиви и часни народни просветитељи, а не као корумпирани „муљатори“, који су преко политике хтели да што брже „доскоче“ у град, пре старијих колега, како су у тексту приказани. 
ли како им се приписује. Ако се имало у виду политичко ангажовање ученика Учитељске школе у Пироту у школској организацији Народне омладине, оно је било слично као и у другим школским организацијама, уз напомену да је ова организација била међу најбољим у пиротском срезу. Сваки члан ове организације имао је три основна задатка: „прво, да учи, друго, да се физички развија и културно уздиже, и треће, да учествује у обнови земље“ (Војчић, 2000: 143). У оквиру другог задатка нарочито је развијано идеолошко-политичко васпитање ученика, ради оспособљавања да као учитељи могу да остварују педагошки принцип: социјалистичке васпитне усмерености својих ученика. Омладинска организација је третирана од наставника и стручних органа школе као значајан фактор формирања личности будућих социјалистичких учитеља. Социјалистичка политичка социјализација ученика је била веома успешна.У сваком годишњем извештају о раду Учитељске школеу Пироту био је и прилог о раду Народне омладине Учитељске школе и њеном доприносу бољим васпитно-образовним резултатима Школе. ${ }^{8}$

Најбољи ученици и ученице у остваривању наведених задатака бирани су за омладинске руководиоце у Школи и ван ње. Они су и по завршетку школовања настављали активност у сеоским организацијама Народне омладине и бирани за чланове основних, регионалних, општинских и среских руководстава ове организације или за њихове председнике. Ученици ове школе су истински добровољно, односно несебично ишли на радне акције, јер су тако васпитавани у школи и омладинској организацији (што могу да потврде преживели акцијаши Учитељске школе у Пироту). Кроз општестручну групу предмета у учитељској школи научили су која им је улога у просвети и у друштвеном животу. За њих су политички ангажман у омладинској организацији и учешће у омладинским радним акцијама биле друштвене вредности и део омладинске и професионалне дужности. Њихови професори су им били узор за то (Козић, Златковић, Станојевић, Апостоловић...). Општи мотив њиховог учешћа у омладинским радним акцијама били су: патриотизам, градитељски занос и жеља да учествују у изградњи земље, извршавање статутарне дужности чланова Народне омладине и програма ове организације. Посебни мотиви били су: самопотврђивање у раду, осамостаљивање од породице, привикавање на колективни живот, подређивање личног интереса друштвеним, хуманост, солидарност, развијање другарства и пријатељства, братства и јединства, упознавање нових предела и насеља, културно-уметнички живот на акцијама, повезивање умног и физичког рада - целовито развијање личности, стицање акцијашког идентитета свесних, напредних омладинаца.

У Учитељску школу у Пироту уписивали су се већином ученици из сиромашних сеоских и мањим делом из градских породица, које нису могле да школују децу ван Пирота. У школској 1953/54. години, од 638 ученика Учитељске школе у Пироту, из сеоских породица било je 426 (66,77\%), из занатско-радничких породица 76 (11,90\%), (Вој-

8 Видети штампане извештаје о раду Учтељске школе у Пироту 1953-1970. 
чић, 2000: 136). Више од половине је било женског пола, од 53,58\% у 1954. до 62,98\% у 1958. (Живковић, 1955: 60; 1958: 90). ${ }^{9}$ Већина њих била је из породица ван општине Пирот. Приликом одласка на омладинске радне акције њихови лични интереси били су потпуно подређени општим, а за ученике са села и оне који су имали у граду неку имовину, или у току распуста зарађивали за школовање и на штету личних интереса. Ученици са села, који нису могли да иду на радне акције, због рада на породичним имањима, нису дискриминисани и са разумевањем је поштовано такво њихово опредељење. Себичност, као етичка категорија је порок и приписује се онима који се у животу руководе искључиво сопственом користи. Они који усклађују своје личне интересе са интересима других људи општим интересом, нису себични. Неки су одлазили на акције са жељом да добију ударничка и друга признања, сачувају или остваре неку функцију у руководству бригада, или у Народној омладини, упишу у своју биографију учешће у радним акцијама, као модни детаљ напредног омладинца, или да заврше курсеве за бригадире (ауто-мото, тракторски, радио-телеграфски, радио-аматерски, кино-оператерски, фото-аматрски...) што није доводило у питање „добровољност и несебичност“ учешћа на радним акцијама. Али нису ни могли да слуте да ће добити било какве „позитивне карактеристике“ од „представника партијске власти“ помоћу којих ће стицати привилеговану професионалну каријеру.

Свима који су прелазили прагове учитељских школа било је стављено до знања да су на конкурсима изабрани као најбољи кандидати, да се оспособљавају за тежак, али племенит позив просветног радника, који ће васпитавати децу, просвећивати одрасле, бити друштвенополитички ангажовани у локалним заједницама. Почеће да раде као приправници учитељи у најудаљенијим селима од градских центара, и нико није калкулисао са тим да ће добити радно место у граду, пре дужег оствареног радног стажа у селима и добрих резултата у раду. С обзиром да је већина ученика била пореклом са села, млади учитељи су разумели потребе мештана и помагали им да унапреде услове рада и живота у селима. Они су знали да је ,учитељски позив... скроман, тражи мого, а враћа мало“ (Селимовић). Учитељску школу у Пироту од 1946-1970. године завршило је 1. 529 учитеља (Николић и Живковић, 1970; Алексић, 1961).

3. Нелогично је поредити број младих сеоских учитеља у Среском комитету Народне омладине Пирот, који су могли да имају статус члана Народне омладине до 27 година, са укупним бројем становништва среза Пирот. Из тог броја изведен је a priori суд о младим учитељима као неморалним политикантима склоним користољубљу. Тек из образовне, професионалне и резиденцијалне структуре чланства овог органа и кадровске политике која је вођена, могло би се нешто закључити зашто је тако било. У кадровској политици су у том периоду уважавани: успех у школи или у раду, резултати постигнути у омладинској организацији, способност за рад са омладином и дужи

9 Живковић, Н, редактор (1955). Мешовита Учитељска школа у Пироту, Извештај за школску 1954/55. годину и за 1957/58. годину. 
боравак на територији среза. Млади учитељи су били веома успешни и ауторитативни у раду са омладином због чега су предлагани у руководства Народне омладине. Ови учитељи се нису сами изабрали у Срески комитет. А из овог погрешног поређења изведен је још један неистинит закључак: сеоски млади учитељи су се незаслужено угурали у Срески комитет НО Пирот да би добили позитивне карактеристике и брже добили радна места у градским школама.

4. Четврта нестина. Нису изостали млади сеоски учитељи са радних акција и из омладинских организација седамдесетих и осамдесетих година прошлог века - због губитка важности наведених „карактеристика“, већ из сасвим других разлога који се, поред већ наведених, налазе у књигама др Драгослава Војчића о школству у општини Пирот, када у већини села није више било ни школа, нити младих учитеља (Војчић, 2000, 2006. и 2009). Млади сеоски учитељи из 1956. године нису се „тихо и лагано повукли из омладинске организације“ јер у њој нису могли да буду седамдесетих и осамдесетих због година, из статутарних разлога. А нових младих сеоских учитеља није било. Све учитељске школе у Србији престале су да уписују у први разред 1970. године. Учитељска школа у Пироту почела је да смањује број уписаних ученика средином шездесетих година. Последњу генерацију уписала је 1969. из које је само 11 ученика завршило школовање 1974. (Војчић, 2000), од тога 7 мушког и 4 женског пола. Од ове седморице четворо нису радили у просветној струци (Р. Шнеле, М. Ристић, Д. Здравковић, Г. Дојкић). О осталој тројици нема података.

5. Поред оних који су настојали да им учешће на радним акцијама буде прагматичан потез за једнократну употребу, пише Николић, „било је и неких који су акцијашењем стекли тако позитивну карактеристику да су касније направили врло успешне каријере“ (Николић, 2016: 172) на републичком и савезном нивоу, или којима је ,акцијашка прошлост корисна за прављење каријере... и у локалној средини (Николић, 2016: 173, болд В. Б.). Међу њима се налазе 10 имена исписаних на порталу Високе школе струковних студија у Пироту као алумни: др Петар Козић, др Драгослав Војчић, др Миомир Ивковић, др Богољуб Пејчић, др Љубомир Коцић, др Ивко Јовановић, др Вјекослав Бутиган, мр Правадољуб Николић, мр Петар Ђорђевић, Видоје Миленковић специјалиста и још 5 имена која су остала у оквиру ,неисцрпљеног списка пиротских доктора и магистара“: др Лука Ђорић, др Радомир Костић, др Ђура Стевановић, др Цветко Китић, др Иван Видановић...

Следи подужи (непотпун) списак од 40 имена, од преко стотине имена учесника у радним акцијама (од којих је половина преминулих), која се налазе у књизи „Радни полет омладине пиротског краја 1944-1989“ (Војчић и др. 2012), али сада са предзнаком акцијашких профитера, који су имали било какве политичке, или руководеће функције у друштвено-политичким организацијама, локалној самоуправи, привредним организацијама, установама, ,невладиним организацијама“, или су остварили стручна и научна звања. Неки са списка су споменути три и четири пута, у зависности од тога да ли су били дирек- 
тори, постдипломци, уредници, политички функционери. Поред наведених имена аутор је додао да их има још на списку. У стварности, ни најпозитивније „карактеристике“ наведених акцијаша (уколико их је уопште било, јер ниједна није описана и образложена од настанка до њеног учинка), нису утицале на њихово високошколско образовање, нити на професионална и научна напредовања у постомладинском периоду, већ знање, способности, вишедеценијски напоран интелектуални рад и резултати у раду. То што су већина њих били руководиоци омладинских радних бригада и акција, говори о одговорној кадровској политици омладинских руководстава у избору најспособнијих омладинаца за те функције. Руководеће искуство са акција било им је касније драгоцено у обављању руководећих функција.

6. Шеста неистина. „Иако је за избор на положаје било поседовање и других квалитета, акцијашење сигурно није било безначајна референца, нарочито на почетку каријере“" (Николић, 2016: 175). И ова тврдња као и неке друге су контрадикторне. Ниједан од именованих није постао директор неке организације на почетку каријере. Није логично тврдити да су успешне каријере појединаца последица учешћа на радним акцијама (,„поле тога, дакле због тога“-post hoc ergo propter hoc) и да од друге половине шездесетих „Акције... нису више биле канал вертикалне покретљивости нити извор неких привилегија“ (Николић, 2016: 208) и „карактеристике губе значај који су имале“ (исто), а да је већина њих те функције обављала, упериоду 1970-1989, када се, по тврдњи у раду, губи значај „позитивних карактеристика".

Најпозитивнију акцијашку карактеристику, ако би их било, требало је да добије Мирољуб Мијалковић из села Блата, рекордер у Пиротском срезу по броју радних акција (11) на којима је учествовао и ударничких признања које је добио. Остао је у селу без политичке и образовне каријере.

Било је и акцијаша који су на радним акцијама кажњавани и искључивани са њих или са њих самовољно одлазили, али су даљим радом, остварили успешне каријере на руководећим местима.

Постојале су карактеристике које су омладинске организације давале за укупан рад у омладинској организацији на лични захтев омладинаца, а не само за учешће на омладинским радним акцијама. Могуће је да су некима биле од користи, некима не. Али за добијање руководећих места у предузећима и установама сигурно не, јер су се за то тражили посебни услови и дуже радно искуство које млади нису имали. Да је проверен утицај наведене карактеристике - ургенције ОК НО Пирот да се Николи Костићу обезбеди место у студентском дому због политичке активности (Николић, 2016, стр. 169), утврдило би се да није постигла никакав циљ, јер именовани није добио домски смештај.

7. У раду су били сумњиви и акцијаши из првих 20 година социјалистичке Југославије који су завршили последипломске студије: „И број оних који су током школовања завршили постдипломске студије био је међу акцијашима процентуално врло велики“ (Николић, 
2026, 179, болд В. Б.). у које спадају и „неки од њих из пиротског краја“, укупно 16 имена, од тога 6 некадашњих команданата. Не наводи се колики је тај број и проценат, нити у односу на шта је тај проценат био врло велики? Да ли у односу на преко 18 хиљада учесника у омладинским радним акцијама из пиротског краја у том периоду, или у односу на оне који су били на радним акцијама, после седамдесетих година прошлог века и касније? Или у односу на “будуће или свршене факултетлије“ који су после седамдесетих били ,ретко на местима команданата“ јер их је у „у омладинској организацији било све мање“(Николић, 2016, 181). Можда је и то био пример утицаја акцијашких карактеристика да 16 именованих помоћу њих, а не на основу високог просека оцена у току основних студија и полагања испита, завршавају студије трећег степена, и то уз редовне радне обаве

8. Остало је нејасно како је усмена карактеристика (“мишљење представника партијске власти о конкретној особи”) о учешћу „конкретне особе“ на радној акцији настајала? Како то да руководиоци радних бригада и бригадири ништа нису знали о тим карактеристикама? А затим како је такво „мишљење“ за учешће на радним акцијама некога из Пирота доспевало до факултета, института, студентских домовима, на пријемним испитима за последипломске студије, приликом избора и реизбора у наставничка и научна звања и избора на руководећа места факултета ван Пирота? Није могуће да нема никаквих трагова о њима.

9. У другој фази развоја омладинских радних акција, после шездесетих, тврди се: „Акције су у том периоду заиста биле добровољне и несебичне, јер нису биле канал вертикалне друштвене покретљивости нити извор неких привилегија“ (Николић, 2016, 208). То се потврђује тиме што су млади ишли на акције због „добре забаве и дружења“, а од тридесетак команданата бригада и седам команданата радних акција у том периоду, само су три завршили факултет. Ни један од њих није био на некој значајнијој политичкој или руководећој функцији. Из овога произилази да су ови акцијаши и њихови команданти „више волели омладинску организацију, радне акције и социјализам“ од напред именованих акцијаша којима је то оспорено (Николић, 2016, 171)? Да ли су они који су на омладинске радне акције ишли да би се „забављали и дружили“, „истински добровољно и несебично“ учествовали у њима, а они који су ишли на акције вођени патриотским, градитељским и сличним мотивима; да упишу жељени факултет; да стекну неку друштвено пожељну квалификацију за рад у предузећима, нису „истински добровољно и несебично ишли на радне акције”? Жеља за „забављањем и дружењем“ третира се овде као друштвено вреднија (несебична) од жеље да се добрим резултатима у раду и понашању „стекне позитивна карактеристика“, или квалификација за друштвено потребна занимања (која се проглашава себичном). Деонтолошка етика то не би могла да прихвати.

Из наведеног податка о степену образовања ових 37 команданата, који су учествовали на радним акцијама, од седамдесетих година прошлог века, јасно је зашто их није било на руководећим мес- 
тима у привредним, друштвеним и политичким организацијама, а не губљење чаробне моћи „позитивних карактеристика“. Мада су неки од њих „доживљавали као животни малер“ (Николић, 2016, 183) то што нису били награђени неком руководећом функцијом. Само та чињеница противречи ауторовој тврдњи да су млади после 1965. године ишли добровољно и несебично на омладинске радне акције.

Опадање интереса младих за одлазак на радне акције почетком седамдесетих година прошлог века има више узрока, међу њима и утицај либералистичке идеологије која је прокламовала индивидуализам, прагматизам и егоизам, као основне друштвене вредности.

10. Један број погрешних тврдњи у раду произашао је због непоштовања методолошких поступака по фазама у истраживању и што нису примењене научне истраживачке методе. У делу рада насловљеном „Метод“ наведена је само једна метода или техника истраживања: анкета, која је примењена само у другом делу рада, код ученика Техничке школе. Обављен је разговор само са двојицом учесника омладинских радних акција пре седамдесетих година и коришћено лично искуство аутора са радних акција, организованих после седамдесетих година прошлог века. Изостала је читава једна фаза истраживања: сакупљање и обрада података (видети: Пејчић, 1996). Није наведен ни један извор о себичним мотивима „младих сеоских учитеља” и ученика „учитељских школа“, нити је „обављен разговор“ са било којим преживелим, тада младим сеоским учитељем и учеником учитељске школе, нити функционером радне бригаде, или радне акције.

\section{УМЕСТО ЗАКЉУЧКА}

Текст „Ррадне акције у социјалистичкој Југославији и могућности њиховог поновног организовања“ приказао је мишљење аутора о радним акцијама у социјалистичкој Југославији и увид у мишљења младих једне средње школе о њиховој спремности да учествују у омладинским радним акцијама, уколико би се поново организовале.

У изради текста уложено је доста рада и личног искуства. Први део под насловом „Радне акције у прве две послератне деценије“, има велики број недостатака. Други део рада нема већих недостатака. Највећи је што одређен узорак за анкетирање није био репрезентативан за средњошколце општине, већ је обухватио само део ученика једне школе. Није објашњено како је формиран узорак. Није примењена Ликертова скала код састављања упитника која би омогућила већу дискриминативност одговора.

Предмет истраживања је методолошки неправилно одређен. „Знатан број примера из пиротске средине није препрека да се изводе закључци који се односе на све радне акције, јер оне нису биле никаква пиротска специфичност“ (Николић, 2016, 164). Тиме је учињено више логичко-методолошких грешака у генерализацији примера (о сеоским младим учитељима, ученицима учитељских школа, руководиоцима радних бригада и акција, добровољности и несебичности одласка на радне акције...) и у извођењу неистинитих закључака, позна- 
тих као „pars pro totus“ (на основу дела неке целине погрешно се суди о целини, посебно ако је хетерогена). Услови рада и живота акцијаша у појединим периодима, на савезним, републичким и локалним радним акцијама битно су се разликовали. Постоје методолошки недостаци у одређивању предмета истраживања, утврђивању циља и задатака истраживања, метода и техника истраживања, основних категорија, хипотеза и индикатора (видети: Милић, 1978). Они су довели до погрешно изведених закључака приликом интерпретације чињеница. Основне категорије „добровољност и несебичност учешћа на радним акцијама“" нису дефинисане па се из контекста може судити да је одлазак на омладинске радне акције био добровољан и несебичан само уколико није био „канал вертикалне друштвене покретљивости нити извор неких привилегија“ (Николић, 2016, 208), а под привилегијом се подразумевало свако лично каријерно постигнуће после тих акција, па и после неколико деценија. Било је убеђивања сеоске омладине, нарочито женске да се пријаве за одлазак на радне акције. Било је и одустајања пријављених, али без санкција. Многи из других слојева младих нису успели да остваре жељу да оду на радну акцију због ограниченог броја учесника.

Уместо да се истраживање фокусирало на културу сећања, ускладиштеној у документима и репрезентативним узорцима, оно је било усмерено на једнострано, фаворизовано, селективно генерацијско сећање 4-5 појединаца и лично искуство аутора. Догме о моралнополитичкој искварености „младих сеоских учитеља“, „ученика учитељских школа“ и промотивној снази „,акцијашких карактеристика“ за остварење професионалних, политичких, руководећих и научних каријера, без чињеничног утемељења, утицале су на неистинито извођење закључака. Због тога поднаслов рада „Радне акције у прве две послератне деценије“" не одговара његовом садржају, јер су у њему наведена, претежно, само имена 40 учесника радних акција и функционера радних бригада из Пирота, у свим врстама радних акција, који су остварили ,значајне каријере“, са навођењем функција које су обављали. Скоро сви наведени акцијаши (40) су били на више омладинских радних акција, неки на прве радне акције са 15 година. Одрицати им ,добровољност и несебичност“ за учешће у омладинским радним акцијама, само зато што су много касније остварили успешне (за неке и завидне) политичке и професионално-стручне каријере је нелогично (non sequitur). Неки од њих су учествовали на четири и више радних акција. Да ли су толико пута били и себични? Да парадокс буде већи на Порталу Високе школе струковних студија за образовање васпитача у Пироту налазе се 15 имена најугледнијих личности, пониклих из школа на чијој је традицији настала ова висока школа, за која се у „Пиротском зборнику“ тврди да су стекла научне и наставничке каријере помоћу“ акцијашких карактерстика“.

Подела радних акција с обзиром на важност ,акцијашких карактеристика“ за остваривање користи и каријера њихових учесника, у прве две послератне деценије и после њих, када оне губе вредност за каријерно напредовање, неправилна је, јер таквих карактеристика 
није било (нелогичност произилази из непостојања принципа поделе).

Нису поштовани ни принципи истраживачке етике што се види из малициозних, неутемељених оцена мотивације појединих група акцијаша за учешће на радним акцијама (руководилаца бригада и радних акција, младих сеоских учитеља, ученика учитељских школа, хиљаде сеоских младића, девојака и других који су се после акција запошљавали у индустрији), који су на радне акције ишли, према тврђењу у раду, ради добијања „позитивних карактеристика“ да би помоћу њих остваривали ,материјална напредовања“, привилегије и уносне каријере. И све то важи не само за пиротске акцијаше, већ и акцијаше Србије и Југославије. Вероватно је било појединаца из ових група који су преко ангажовања у омладинској организацији желели да остваре политичке каријере, али само учешћем у радним акцијама то нису могли да остваре, јер је за то била потребна вишегодишња перманентна политичка активност, резултати рада у њој и стално доказивање да су „на линији“ борбе за изградњу социјалистичког друштва. Радне акције су биле део политичке биографије, значајне за оне који су желели да започну политичку каријеру, са појединачним изузецима, до нивоа статистичке грешке.

Измишљеним и хипостазираним ,акцијашким карактеристикама““ је у анализираном тексту приписана чаробна моћ за остваривање каријеристичких циљева. Оне су фетишизоване и у чаролију претворене тврдњом да су помоћу њих именовани остварили политичке, професионалне, руководеће па чак универзитетске и научне каријере. Приказане су на потпуно произвољан, необјективан, неаргументован, изопачен и нелогичан начин до бесмислености (акцијашке карактеристике су утицале на полагање испита, завршавање факултета, магистарских теза и докторских дисертација, избор директора и декана).

Све то би се могло подвести под логичке грешке „не следи (non sequitur), непознавање предмета доказивања (ignoratio elenchi) и тражење разлога (petitio principi).

Опчињен тим имагинарним карактеристикама и њиховим утицајем на каријере бивших акцијаша, описаним на скоро 6 страна (170-175. стр, од 10 посвећеним радним акцијама у првих 20 година постојања у Социјалистичкој Југославији, и још на 179. и 180. стр.), аутор није приметио да су код ових акцијаша постојали: патриотизам, стваралачки ентузијазам, социјалистички идеали, идентификација са градитељима социјалистичког друштва и други мотиви, а о којима може да се чује и прочита у успоменама акцијаша из тог периода.

Претходно наведене групе учесника у омладинским радним акцијама су негативно оцењене и стигматизоване у памфлетском маниру да би се умањила вредност њиховог учешћа на омладинским радним акцијама. Проглашени су за акцијашке профитере, без икаквих доказа. Тиме су ове групе оклеветане, њихово учешће на радним акцијама омаловажено, као и остварени резултати рада, а именованим појединцима повређени част и углед (половини постхумно).

За последње генерације акцијаша, од друге половине шездесетих, тврди се да су одлазила на радне акције генерално “истински 
добровољно и несебично”, ради дружења и забаве, а њихови руководиоци лишени привилегија на руководеће положаје у општини, као заслужених награда. Оне су позитивно идеализоване да би се показале да су по “добровољности и несебичности” надмашиле претходне акцијаше.

Оваква субјективна, уобразиљом створена, конструкција приказивања мотивације за одлазак на омладинске радне акције у пиротском крају, у првих 20 година и после њих, није стручно аргументована. Ако се генерализује и на друге крајеве у социјалистичкој Србији и Југославији, па се лична предрасуда уопшти на поједине групе акцијаша, како је учињено у овом раду, она је скандалозна. „Акцијашке позитивне карактеристике“" су у Бодријаровом (Baudriar) смислу первертирани симулакруми (измаштане фикције), које су замениле реалност различитих животних путева којима су ишли некадашњи учесници радних акција после њих. Сигурно је да непостојеће „,акцијашке позитивне карактеристике“ нису могле да имају утицаја на остварене политичке, стручне, професионалне и научне каријере учесника радних акција. Емпиријским испитивањем преживелих акцијаша из напред наведених група, на случајном узорку, о тврдњи да они или други млади из ових група, “нису добровољно и несебично ишли на радне акције“, већ ради „позитивних карактеристика“ показала се, неистинитом. То може да провери свако обичним, неструктурираним упитником.

\section{ДОДАТАК}

Аутор анализираног рада је обавио разговор само са два учесника омладинских радних акција, организованих у Социјалистичкој Југославији, у прве две послератне деценије двадесетог века.

У прилогу ове анализе дати су резултати емпиријског пилот истраживања кроз интервјуе са 146 испитаника, од којих су 86,25\% били на омладинским радним акцијама од 1947. до 1965. године. Као ученици учитељске школе били су на омладинским радним акцијама $51,14 \%$ испитаника, као гимназијалци, ученици економске школе и студенти 29\% и других школа 6,10\%. У контролној групи $13,74 \%$ интервјуисаних нису били на радним акцијама.

Међу интервјуисаним је било: 8,90\% доктора наука, 3,42\% магистра и специјалиста, $40,41 \%$ са високим образовањем, $28,76 \%$ са вишим образовањем, $16,38 \%$ са средњим образовањем и $2,05 \%$ са КВ и ВКВ квалификацијом. Међу њима 23,97\% биле су жене.

Двадесет и четири интервјуисаних $(16,48 \%)$ прочитало је у целости текст у „Пиротском зборнику“ пре интервјуа. Интервју је био на случајном узорку, приликом случајног сусрета у граду са учесницима у омладинским радним акцијама (неучесницима) или приликом телефонских контаката са оним који су живели ван Пирота (14) и у Пироту (6). Испитаници су веома радо пристајали да говоре о радним акцијама, које су им остале у најлепшим успоменама и да одговоре на постављена питања. Петнаест процената од њих је наведено у тексту 
Горана Николића као пример да су акцијашењем стекли „тако позитивну карактеристику“ на основу које су касније „направили врло успешну каријеру“ у Београду, Нишу или Пироту. Сви су имали више од седамдесет година.

Интервју је обављен и са 10,58\% испитаника који нису били на радним акцијама, од тога $6,84 \%$ који су били ученици Учитељске школе у Пироту и 4,10\% који су били ученици Гимназије у Пироту. Три испитаника од поменутих 6 , некадашњих ученика гимназије, обављали су руководеће функције у општини.

Приликом тражења дозволе за објављивање њихових изјава са иницијалима имена, већина је захтевала да се оне објаве под пуним именима, неки и са пуном адресом и са жељом да се суоче са аутором текста из „Пиротског зборника“ ради добијања објашњења зашто је писао неистине или лажи. Из изјава су изостављане увредљиве речи увређених некадашњих бригадира упућених аутору неистинитим писањем.

Постављена су им четири питања:

1. Да ли знате неке који нису ишли на омладинске радне акције добровољно и несебично?

2. Да ли су неки омладинци ишли на радне акције ради добијања „позитивних карактеристика“ које би им служиле за остварење неке погодности (бржег запошљавања у граду, уписивања жељеног факултета, добијања стипендије, студентских домова, или других привилегија?)

3. Зашто сте Ви и ваши другови/другарице ишли на омладинске радне акције и да ли сте на основу учешћа на њима остварили неку привилегију која није била доступна онима који нису ишли на радне акције?

4. Шта мислите о тврдњи аутора Г. Н. да ,за неке учешће на омладинским радним акцијама није било ни добровољно ни несебично“" као што су „млади сеоски учитељи“, „ученици учитељских школа“, млади са села, или они који су касније били политички функционери, директори радних организација, установа и професори универзитета, који су, по његовом мишљењу, ишли на радне акције ради добијања „позитивних акцијашких карактеристика“ помоћу којих су остварили наведене каријере и друге привилегије.

Сви интервјуисани тврдили су да се на омладинске радне акције ишло добровољно и несебично, јер није било спољашње принуде, нити тежњи за привилегијама. Нису знали ни један пример одласка на радну акцију који није био добровољан и несебичан.

Као лични мотиви интервјуисаних за учешће на радним акцијама били су најчешће: понетост општим омладинским градитељским ентузијазмом, патриотизам, жеља да изврше омладинску дужност, да доживе колективни живот и рад, учешће у културно-забавном животу у омладинским насељима, да учврсте и прошире другарство и пријатељство, упознају нове пределе и младе људи у Србији и Југославији, да допринесу учвршћивању братства и јединства југословенских народа. 
За „,акцијашке позитивне карактеристике“ нису ни знали, нису очекивали неку привилегију од учешћа на акцијама, нити су неку остварили. Није им познато да су на основу учешћа на раднима акцијама неки остварили успешне каријере.

Само један је навео да се као учитељ политички ангажовао очекујући бржи долазак из села у град, али му се очекивање није остварило.

Други је истакао да је било учитеља запослених у сеоским школама који су после више година напуштали професију да би се запослили у граду.

Нису се слагали са тврдњом да су наведене групе могле да остваре професионалне и политичке каријере са непостојећим „позитивним акцијашким карактеристикама“, а учешће на омладинским радним акцијама није био ни довољан, нити нужан услов за остваривање неке каријере.

У даљем тексту следи избор коментара уз одговоре на постављена питања 15 учесника у омладинским раднима акцијама на неистине које је Горан Нколић изнео о њима у свом тексту и 5 који нису учествовали у овим акцијама., од 146 датих.

\section{А. Коментари уз одговоре некадашњих ученика учитељске школе у Пироту (сада пензионера)}

1. J. В, професор: „Као ученик првог разреда Учитељске школе, са 15 година, пријавио сам се да идем на радну акцију. Лекар је на прегледу хтео да ми то онемогући, јер нисам имао 50 килограма. Нисам пристајао да ми одреди ограничену способност за учешће на акцији само за доношење воде бригадирима. Једва сам измолио да ме прогласи здравим за акцију, уз обећање да ћу повећати тежину. Погрешио је онај ко је тврдио да смо ишли на акцију због 'позитивних карактеристика'“.

2. П. М, просветни, културни и социјални радник и руководилац установе: „О ученицима учитељске школе и младим учитељима аутор наведених тврдњи ништа не зна, нити је хтео нешто да сазна. Намере му нису биле да саопшти истину о њима“.

3. В. Ж, наставница: „Била сам на две локалне радне акције. На њима смо радили са одушевљењем. Писање о ученицима учитељске школе, младим учитељима и успешним акцијашким каријерама нема везе са тадашњом реалношћу“.

4. Р. Ж, наставник разредне наставе: „Порицање добровољности и несебичности учешћа ученика учитељских школа на омладинским радним акцијама и приписивање им намере да се домогну некаквих карактеристика је злонамерно“.

5. Д. Н, дипломирани политиколог: „Нисам могао да прежалим што као ученик првог разреда учитељске школе нисам примљен да идем на савезну радну акцију. Касније сам ишао на акције, као и моји другови, али не због карактеристике и привилегија. Као учитељ организовао сам многе акције за уређење села. У сваку кућу ушао сам 
више пута да убеђујем домаћине да учествују прилозима у електрификације села и изградњи водовода“.

\section{Б. Коментари уз одговоре некадашњих ученика гимназије и економске школе у Пироту (сада пензионера)}

Имајући у виду тврдњу Николића да су неки ученици гимназије ишли на омладинске радне акције да би уписали жељене факултете, добили стипедије, студентске домове и да су ,акцијашењем стекли тако позитивну карактеристику да су направили врло успешне каријеpe, на савезном и републичком нивоу“, требало је проверити да ли су ученици пиротске гимназије ишли на радне акције добровољно и несебично или због тих "позитивних карактеристика“" и остварења успешних каријера помоћу њих.

1. Ђ. М, дипломирани економиста, општински функционер: “На савезну акцију кренули смо само нас 16 гимназијалаца 1958. године, после строге селекције од великог броја пријављених, док су матурски испити били у току, тако да они који нису били ослобођени усменог дела испита, нису знали коначни успех на матури. Кренули смо са одушевљењем да градимо земљу, без знања да постоје неке акцијашке карактеристике које би нам користиле за студије“.

2. Љ. Д, професор: „Био сам на 4 акције а за акцијашке карактеристике нисам знао. Ко тврди да су ученици средњих школа ишли на омладинске радне акције педесетих година због 'позитивних карактеристика' полазио је од себе и ишао на радне акције због 'позитивне карактеристике'. Свој мотив за учешће на омладинским радним акцијама пројектовао је на друге“.

3. С. J, професор, руководилац установе: „Радне акције су биле тако популарне да на њих нису могли да оду сви који су желели. Није било никаквих калкулација око наводних акцијашких карактеристика. Уписао сам факултет 1962. године и знам да смо ја и други места у студентским домовима добијали искључиво на основу успеха у гимназији, на студијама и материјалног стања породице. Студенти са бољим успехом добијали су боље собе. Учешће на радним акцијама, рад у омладинској организацији и Савезу комуниста, нису били критеријуми за смештај у студентски дом“.

4. О. П, дипломирани економиста. Прочитала цео текст Г. Н. „За време учешћа у неколико акција нисмо знали ни за какве акцијашке карактеристике. Била сам стипендиста од прве године факултета до завршетка, али на основу одличног успеха, а не некакве карактеристике“.

5. Др В. 3., професор универзитета, некадашњи председник Општинског комитета Народе омладине Пирот 1959-1962.: „Никаквих акцијашких карактеристика није било. На лични захтев појединих омладинаца/омладинки Општински комитет је, на основу података из основних организација, давао писане карактеристике о њиховом раду у омладинској организацији. Оне су најчешће служиле за њихово укључивање у рад у омладинским организацијама ван подручја општине и среза Пирот“". 


\section{В. Коментари уз одговоре оних који су завршили гимназије ван Пирота (сада пензионера)}

1. Др Н. С., универзитетска професорка, завршила гимназију у Цетињу и Скопљу, радила у Пироту: „Акције су нас привлачиле због жеље да се укључимо у изградњу земље и велике концентрације младости из свих крајева Југославије. Никада нисам физички радила па ми је било тешко на акцијама, али сам добијала похвале за резултате рада. Привилегија на основу учешћа у радним акцијама није било. Једино приликом пријема у Савез комуниста предлагачи су навели да сам учествовала на радним акцијама“.

2. С. Ж., дипломирани архитекта, завршила гимназију у Димитровграду, радила у Пироту: „Неистинито писање о утицају акцијашких карактеристка на наше професионалне каријере је неодговорно. Уз то и увредљиво, јер нам најлепше младалачке успомене са радних акција жели да замрачи, учини их неверодостојним у очима наше деце и унука. Читајући о тим карактеристикама помислиће да смо их лагали причајући им да смо ишли на добровољне омладинске радне акције без икаквих калкулација“.

3. Др Љ.М., професор емеритус, омладински функционер, функционер факултета и универзитета. Упознат са текстом Г. Н. „Тврдње о повезаности академских, руководећих и политичких каријера наведених личности са њиховим учешћем у омладинским радним акцијама дискредитује не само те личности већ читаве генерације које су допринеле економском, политичком а нарочито културном развоју Пирота. То ниједан разборит човек не може да прихвати.“

4. С. В., наставник, руководилац установе и службеник: "Мада сам сеоско дете, био сам на три радне акције (1948-1950) и био похваљиван на њима. Никакве привилегије нико није имао за учешће у радним акцијама. Радио сам у селима 10 година и примљен за референта за просвету СО Пирот. Ниједан млади учитељ, или наставник, који је радио у селима, а био на радним акцијама и политички се ангажовао, није са нама 'средио да што брже' добије посао у градској школи“.

5. Д. 3., професор универзитета: „Прочитала сам текст и питам се који су мотиви аутора да пише тако нешто срамно. Слажем се да је потребно реаговати, јер у случају да изостане другачије, аргументовано виђење, остаје ружна слика - не само о појединцима, него и о институцији радних акција (поносно истичем да сам била учесник једне радне акције као председник Збора бригадира - ауто пут код Велике Плане)“. 


\section{Г. Коментари уз одговоре некадашњих ученика других школа (сада пензионера)}

1. М. Н., виши медицински техничар, политички функционер. Био на изградњи пруге „Брчко-Бановићи“. „Тврдња да смо ишли на радне акције због ‘позитивних карактеристика' и привилегија које су долазиле са њима је лаж. Не могу да разумем чему треба да служи“.

2. Н. Б., дипломирани социјални радник, био на руководећим функцијама. Прочитао цео текст Г. Н. Наведен као пример чија је ,,акцијашка прошлост била корисна за прављење каријере у локалној средини“. „Неистине о онима које тврде да нисмо ишли на омладинске радне акције добровољно и несебично треба да буду исправљене од оног ко их је написао. Уколико их не докаже, све док има преживелих учесника омладинских радних акција, они ће их сматрати лажима. То ће и другима говорити и писати да се демантују као злонамерне“.

3. С. М., ВКВ радник, командант сеоско-радничке бригаде од 100 бригадира и 40 бригадирки 1959. На акцију отишао ускоро после одслужења војног рока. Бригада је радила два и по месеца. "Неко ко пише да неки омладинци нису ишли добровољно и несебично на омладинске радне акције, већ да остваре неке привилегије, или је злонамеран или ништа не зна о омладини тих година. Навођење Козића, Војчића и других, које нарочито поштујем, као примере за остваривање каријера на основу тога што су били команданти бригада је неодговорно. Као командант бригаде нисам остварио никакву привилегију, нити моји бригадири и чланови штаба. Као привилегију не сматрам пола радничке плате коју сам добио за покриће режијских трошкова стана док сам био на радној акцији. Волео бих да видим писца и да му то лично потврдим.“

4. Г. Г., техничар, био на радној акцији код Алексинца 1958.: „Сви из моје школе који су били на омладинској радној акцији су потпуно добровољно и несебично отишли на њу. Неки посетиоци бригаде из Немачке су се чудили што радимо бесплатно. Са једним од њих сам се сликао и имам ту фотографију. Ко тврди да су неки од нас ишли на радне акције ради личне користи 'једе трице', инсистирам да се тако напише у мојој изјави“.

5. Ј. М., КВ радница: „Била сам у сеоској Врањско-пиротској бригади на изградњи аутопута 1959, два месеца. Командант бригаде био је Слободан Димитријевић. „Нико из наше бригаде, па ни командант није остварио неку привилегију“.

\section{Д. Коментари уз одговоре оних који су завршили учитељску школу у Пироту, а нису ишли на радне акције насељског типа (сада пензионера)}

Сви ученици Учитељске школе у Пироту учествовали су на једнодневним омладинским радним акцијама, у саставу радних бригада, на уређењу школског дворишта, школских просторија (кречење, фарбање столарије, израда учила, изградњи фискултурне сале,...), на одр- 
жавању градских паркова, дворишта предузећа и установа, скидању плодова на Пољопривредном добру „Барје“, пошумљавању голети, санирању путева...

1. М. Ђ., професор. Супруга му је била на више акција. „Као сеоско дете нисам могао да идем на радне акције због рада на породичном имању. Нико ми није то замерао. Нисам приметио да су они који су ишли на омладинске радне акције само на основу њих имали неке привилегије у школи и касније“.

2. А. Д., наставник: „Мој брат је ишао на радне акције, а ја сам морао и за њега да радим у селу. Нисам имао никакве неприлике због тога што нисам ишао на радне акције. Није истина да су мој брат и други који су ишли на радне акције имали било какве привилегије. Мој брат је више пута доносио ударничке значке са радних акција, а био је два пута командант бригада““.

3. Т. П., наставник: „Нити нас је неко присиљавао да идемо на радне акције, нити смо били дискриминисани због тога што нисмо ишли на њих. А тврдња да су неки најбољи ученици Учитељске школе у Пироту остварили успешне каријере на основу акцијашке карактеристике је бесмислена“"

4. М. Д., наставник: „У току лета морала сам да радим у селу са родитељима. Они ученици који су ишли на радне акције нису имали било какву предност у школи и касније од нас који нисмо ишли“.

5. В. М., професор: „Нисам ишао на омладинске радне акције због рада на породичном имању, мада сам знао да се на њима мање ради него у селу. Нисам имао никакве последице због тога, нити су они који су ишли на радне акције имали неке предности због тога. Посебно не они којима се приписују успешне каријере (Војчић и други)“.

\section{Ђ. Коментари уз одговоре оних који су завршили гимназију а нису ишли на радне акције (сада пензионера)}

1. М. М., професор, руководилац установе: „Нисам ишао на радне акције јер сам био потребан родитељима за рад на имању у селу. Због тога нисам имао никакве последице. На хиљаде су прошли кроз омладинске радне акције и нису остварили никакве уносне каријере и супротно томе многи су остварили успешне каријере без учешћа на омладинским радним акцијама. То највише говори о утицају акцијашких карактеристика на каријерно напредовање“.

2. Н. М., професор, био на функцијама у општини: „Веома добро знам да они који су ишли на радне акције нису имали никаква преимућства од мене како у току студија, тако и касније. Само човек са екстремним мишљењем може да тврди супротно од онога што скоро сви знају о томе“.

3. Б. Ж., професорка: „Уписала сам архитектонски факултет 1949. године без икаквих проблема, као и остали студенти који су то желели. Уопште се нисмо разликовали међу собом на основу учешћа на радни акцијама, нити је било повлашћених. Није ми било познато 
да је учешће у омладинским радним акцијама био услов за уписивање на неке факултете“.

4. J. J., професор, директор установе: „Уписао сам факултет 1951. Није било никаквих предности за учеснике омладинских радних акција приликом уписа на факултете, нити за коришћење других повластица у односу на оне који нису били на радним акцијама“.

5. Б. Н., професорка. Супруг јој је учествовао на радним акцијама. "За време студија и касније нисам примећивала да су учесници у омладинским радним акцијама, па и мој супруг, имали било какве привилегије. Завидела сам другарицама које су биле на радним акцијама док сам радила са родитељима на њивама“"

\section{ЛИТЕРАТУРА}

Алексић, П., прир. Споменица Учитељске школе у Пироту 1920-960. Пирот: Наставнички колектив Учитељске школе у Пироту, 1961.

Војчић, Д. Основно школство у Пиротском крају 1941-2001. Пирот: Виша школа за образовање васпитача, 2006.

Војчић, Д. Од основне до више школе у пиротском крају, школска мрежа 1815-2005. Пирот: Музеј Понишавља, 2009.

Војчић, Д. „Учитељска школа у Пироту од 1945-1960“. У 80 година образовања и васпитања учитеља и васпитача у Пироту, уредио Р. Живковић, 113-146. Пирот: Виша школа за образовање васпитача у Пироту, 2000.

Војчић, Д., В. Панчић и Г. Николић. Радни полет омладине пиротског краја. Пирот: Историјски архив и Удружење учесника омладинских радних акција Пирот, 2012.

Годишњи извештаји о раду Учитељске школе у Пироту, 1954-1989.

Ђорђевић, Г. Н. и В. Д. Војчић. Паклештица, село и школа. Пирот: Народна библиотека, 2001.

Живковић, Н., ред. Мешовита учитељска школа у Пироту. Извештај за школску 1954/55. годину. Пирот, 1955.

Живковић, Н., ред. Мешовита учитељска школа у Пироту. Извештај за школску 1957/58. годину. Пирот, 1958.

Кузмановић, Б. и др. „Студентски протест 96/97“. Психолошка истраживања 13 (2003).

Милић, Војин. Социолошки метод (друго допуњено издање). Београд: Нолит, 1978.

Николић, Г. „Радне акције у социјалистичкој Југославији и могућности њиховог поновног организовања“. Пиротски зборник 41 (2016): 161210.

Николић, П. и Р. Живковић. Пет деценија Учитељске школе у Пироту. Пирот, 1970.

Пејчић, Б. Методологија емпиријског научног истраживања, II. 
Београд: Универзитет у Београду, Дефектолошки факултет, 1995.

Споменице појединих генерација учитеља Учитељске школе у Пироту (1952, 1957, 1958, 1959).

Цветков, Б. „Подела предмета на наставнике“. У Основна школа „Вук Караџић 1815-1995“, уредио J. Николић, 172-233. Пирот: Народна библиотека и Основна школа „Вук Караџић“, 1995.

\title{
THE POWER OF "CHARACTERISTIC ACTIONS" POSITIVE" AND NOT POWER TO THE LARGE GROUP OF BRIGADER DISCLAIMS THE VOLONTARY AND UNSELFISH PARTICIPATION IN YOUTH WORKING ACTIONS
}

\begin{abstract}
Summary
This text was created as a reaction to the work "Youth work in actions in the socialist Yugoslavia and the possibilities of its reorganization", of Goran Nikolic, published in Pirotski zbornik no. 41. The refuted claims made in it paper that there were in the first 20 years of organizing youth working actions in Socialist Yugoslavia, the groups of young people went to of working actions to used them to accomplish some privileges, professional, political and other managerial careers. It rejected the assertion are that "young village teachers" went to youth working actions and "politically engaged in the desire to get a positive characteristic and as such that the competent school authorities are making faster movements to the city. The same was behaev of those who had just been preparing for the teacher's callups of teachers' schools", because they were not of the fact found or argued. The refuted The claim that the heads of the working brigades and individual of that, through "action positive characteristics", have achieved academic, scientific and university careers, leadership positions in economic organizations and institutions. The dispute the claim that these groups of young people did not go to youth working actions "truly voluntarily and unselfish", but because of "action positive characteristics", material benefits and various privileges. It points to methodological and logical incoherence in the interpretation of some data in relation to the previous claims of the author of the text on working actions and the conclusions drawn.
\end{abstract}

Key words: actions characteristics, young village teachers, student of teachers schools, careers, functionaries. 